\title{
Nationalism without a Nation: \\ The rise and fall of Zulu nationalism in South Africa's transition to democracy, 1975-1999
}

Laurence Piper

Political Studies, School of Human and Social Sciences

University of Natal, Pietermaritzburg

South Africa

Introduction

On the eve of the first democratic election of 27 April 1994 the headlines of South Africa’s newspapers read the same: ‘Zulus on the march’ (Natal Witness 29 March 1994), ‘KwaZulu gears for civil war’, 'Fear, the Beloved Country (Weekly Mail \& Guardian March 25-30 1994). The 'warrior' Zulu nation, famous for routing the British army in 1879 before finally succumbing, appeared to be on the march again. On 17 January 1994 at the government buildings in Pretoria, King Goodwill Zwelithini (1994) declared before 60000 'subjects' that he had come to claim 'the Zulu right of self-determination' as the proposed post-apartheid constitution was 'not predicated in our self-determination’. Rallying against a ‘Xhosa-dominated’ African National Congress (ANC), Zulu nationalist resistance was organised through the Inkatha Freedom Party (IFP) of Mangosuthu Buthelezi, the nephew of King Zwelithini. In the months preceding the 1994 election the IFP conducted a massive anti-election campaign in the province of KwaZulu-Natal, historically the home of the Zulu kingdom. In rural areas, which the IFP controlled through its monopoly of the KwaZulu government, this resistance this took the form of sequestration from any outside penetration. In urban areas, mostly dominated by the ANC, violence between IFP and ANC supporters flared dramatically. Frustrated with IFP brinkmanship, the ANC and National Party (NP) pushed ahead with election preparations, resolving to meet force with force. Such was the standoff that by early April 1994 South Africa seemed poised on the brink of an ethnically-flavoured civil war. 
Thankfully (and to the surprise of most) on 19 April 1994, barely a week before the election, the IFP acquiesced and decided to participate. For the short term at least, civil war was averted. Nevertheless, many observers expected Zulu nationalism to continue in new but nevertheless imperative form after the election, calling into question South Africa's new political order (see Taylor 1994). Remarkably however, it did not. By the local government elections of 1996 the IFP’s militant Zulu nationalist rhetoric and mobilisation was replaced by a conservative-liberal and co-operative alternative. Moreover, KwaZulu-Natal was peaceably part of South Africa, the Zulu King had publically abandoned the IFP and Zulu nationalism, and political violence had dwindled away almost completely. Today, the IFP and ANC are voluntary partners in both the national and KwaZulu-Natal governments. From once threatening to explode with a bang, Zulu nationalism has withered away with a whimper.

This paper sets out to explain this rupture. More especially it interrogates the primordialist assumptions about Zuluness advanced in the IFP's transition rhetoric and by many observers, usually white and western, for whom an essential Zuluness seems a pet myth. What is missed in these accounts is that the Zulu nationalism of the transition was driven by a particular political party, the Inkatha Freedom Party (IFP) which expediently embraced and then jettisoned Zulu nationalism. Moreover, most Zulus are not Zulu nationalists. By reflecting elite rather than popular concerns, the IFP's Zulu nationalism constitutes what Lonsdale (1994) and Berman (1998) term ‘political tribalism' and Hutchinson (1994) names ‘political nationalism'. Indeed, it is the very disjuncture between the party and the people which allowed for the easy abandonment of Zulu nationalist politics after 1994. Had a truly popular Zulu nationalism been unleashed it is inconceivable that it would have dissipated so quickly without realizing its objectives. 
This argument is made in two ways. First I trace the rise and fall of Zulu nationalism within the politics of the IFP, demonstrating that its waxing and waning can only be understood in terms of the changing strategies of the party. In turn, the shifts in party strategy are related to an ongoing competition with the ANC and its allies, initially over leadership of South African resistance politics and subsequently over the process to, and content of, a post-apartheid state. While the manipulation of Zuluness for political ends by the IFP is well documented by leftist scholars (Maré \& Hamilton 1987, Mzala 1988, Forsyth 1989, Maré 1992), this paper offers a more sophisticated account of IFP politics as a unique attempt at resistance politics which explains the turn to Zuluness as a second choice strategy driven by competition and conflict with a rival. By foregrounding the deliberately ambiguous character of Inkatha's anti-apartheid politics this account eschews the leftist tendency to reduce Inkatha to an apartheid satrap. By drawing out the relational nature of Inkatha's turn to Zuluness this account also avoids the (usually) rightist tendency of reducing Inkatha to a Zulu nationalist project, albeit of an elite, populist version. The importance of a more complex reading of Inkatha's politics is reinforced by the fact that none other than the KwaZulu-Natal ANC itself embraced Zuluness for instrumental ends during the negotiations years.

The second line of argument picks up the 'politics of Zuluness' from the popular point of view, arguing the constructions of Zuluness invoked by both the IFP and ANC during the transition were embraced only partially by ordinary people. Thus while a widespread sense of 'being Zulu' exists, typically articulated in terms of language, place and descent, the meanings attached to it vary to the extent that neither the IFP's 'Zulu nation' nor ANC's 'rainbow nation' can be said to exist. This is not to say that many in the IFP do not believe in the Zulu nation as primordially presented, but it is to say that most Zulu people do not. To put the matter differently, both the IFP's 
Zulu nationalism and the ANC's rainbow nationalism were, in Ranger's (1994) terms, 'invented from above' rather than 'imagined from below'. If there is to be a future for Zulu nationalism or rainbow nationalism for that matter, more 'imagining' needs to be done, not least as the history of these imaginings in KwaZulu-Natal has been one that has generated hybrid identities of 'black' and/or ‘African’ and/or 'Zulu’, rather than simply ‘Zulu’ (Sitas 1990, la Hausse 1992, Campbell et al 1995).

There are two important theoretical distinctions which underlie my argument. The first is the distinction between an ethnic group and a nation. An ethnic group is a people (Wallerstein 1991:71), or community believed to be of common descent, as indicated by shared cultural attributes. A nation is a people, often an ethnic group, who claim the right to political autonomy. This definition reflects the common-sense understanding that there exist many ethnic groups which are not nations (Jewish American), and that there exist nationalist movements, like the ANC, who claim self-government for a people who are multi-ethnic. Moreover, this definition eschews the onesided readings of the nation as objectively given by culture (Renan 1994:17) or institutions (Giddens 1985:119) or both (Smith 1991:14); or as subjectively given through the invention of élites (Kedourie 1960:13, Hobsbawn 1990: 10). In brief, both the objective conditions of peoplehood and a subjective political belief are required. This is a claim analogous to Marx's distinction between a class-in-itself and a class-for-itself; or the distinction between a category, which is socially-ascribed, and a group, which is also self-ascribed. Thus for the Zulu ethnic group to be a nation, a common belief in the right to political autonomy is required. This is not the case. The Zulu are an ethnic group politically divided in a way which eliminates the possibility of a common nationality.

This latter point is bolstered by evidence that refers to the national self-understanding 
of Zulu people, processes which John Hutchinson (1994) terms ‘cultural nationalism’ and John Lonsdale (1994) terms ‘moral ethnicity'. Hutchinson’s cultural nationalism and Lonsdale moral ethnicity both refer to the process of identity-building around moral issues during times of social change. While they describe the nature of these processes somewhat differently (Lonsdale focuses on the African experience and Hutchinson more on the European) both share a focus on social and cultural debates over what it is to be a member of the group in question. My point is that the evidence from these debates amongst the Zulu, throughout the twentieth century, have not simply affirmed being Zulu, but often a hybrid of Zulu and black, or Zulu and African, identities. Race and ethnicity have been intertwined in the self-understanding of KwaZulu-Natal's people thus undermining the basis for Zulu nationalism.

\section{Party Competition and the Politics of Zuluness}

The IFP's militant Zulu nationalism of April 1994 was the climax of a fifteen year power struggle with the ANC and its allies. This power struggle began in the late 1970s over the leadership of South African resistance politics but after 1990 mutated into a struggle over the process to, and content of, a post-apartheid state. Prompted by contingent factors, not least the ambitions of key leaders, the IFP/ANC power struggle moved from the representational (and national) in the late 1970s to the territorial (and provincial) in the mid-1980s with the parties battling violently for control over black areas of KwaZulu-Natal. The history of this territorial conflict is fully understandable only against the backdrop of an apartheid state 'bifurcated' into rural and urban branches with distinct elites, constituencies and power-relations (Mamdani 1996). Even before conflict erupted, Inkatha was intertwined with the rural branch of indirect rule, the KwaZulu 
homeland, whereas ANC-aligned organisations blossomed in the urban branch of direct rule. The 1980s conflict greatly sharpened this nascent rural/urban political divide. Indeed, it is as a direct result of being out competed by the ANC in the urban domain that the IFP chose to defend the KwaZulu homeland, traditional leaders, the Zulu king and the 'Zulu nation'.

During the 1990s the focus of the IFP/ANC power struggle moved from the territorial to the institutional with the negotiation of a post-apartheid state and thus from the provincial back to the national. The IFP soon found itself marginal to an ANC/NP dominated negotiations process which promised to all but eradicate the IFP's power-base. Consequently, the IFP became more confrontational and Zulu nationalist to try and force its way into the heart of the negotiations process. It is this exclusion from pact-making which explains the IFP's turn to militant Zulu nationalism and the threat of civil war on the eve of the 1994 election. Ironically then, the IFP's Zulu nationalism was a more a cry for inclusion in South Africa's future rather than a demand for a sovereign Zulu state. Similarly, the IFP's gradual abandonment of militant Zulu nationalism after 1994 is explained by the party's inclusion in the new deal. On the one hand, rural support in KwaZulu-Natal meant the IFP was able to secure a new power-base under democracy while, on the other, liberal-democratic governance made old confrontational strategies redundant, even counterproductive. In brief then, the rise and fall of Zulu nationalism was a function of a contingent rivalry between political elites that can only be fully understood against the backdrop of the formation and reformation of the bifurcated state.

\subsection{The formation of Inkatha in 1975}

The Inkatha Freedom Party began as Inkatha in 1975. Launched by Mangosuthu 
Buthelezi, head of the KwaZulu government, Inkatha can only be understood against the background of the KwaZulu homeland, the repressive successes of the state and Buthelezi's peculiar form of resistance politics. Building on the colonial practice of indirect rule (Etherington 1989), the homeland system constituted one branch of what Mamdani (1996) describes as a state 'bifurcated' between the domains of direct and indirect rule. The domain of direct rule, 'white South Africa' in apartheid discourse, incorporated the urban areas and white farmland, amounting to $87 \%$ of South Africa. The domain of indirect rule, known variously as 'the reserves', 'homelands', 'Bantustans' or 'self-governing territories' comprised rural areas covering just $13 \%$ of the total land area. In the former, governance was by democratic institutions and European law, but only white people were regarded as citizens and incorporated into civil society. In the latter, governance was by 'traditional' authorities under 'customary' law. Black South Africans were thus tribalised as 'subjects' in a decentralised branch of the state.

While the National Party's apartheid policy of 1948 looked to refurbish the domain of indirect rule as the rightful 'homelands' of 'ethnic' black South Africans, it was only with the advent of Hendrick Verwoerd as Prime Minister in 1959 that these homelands were conceptualised as nascent nation-states and devolved certain administrative powers (Posel 1991). In addition to governance by chiefs at the local level and regional level, Verwoerd's 'grand apartheid' added a third 'territorial' level which included a legislative assembly, government and administration (Horrell 1973). While lack of political autonomy and heavy economic dependence on Pretoria meant that grand apartheid was little more than an ethnic smokescreen to conceal the ongoing oppression and exploitation of black South Africans (Greenberg 1987), it did reform the homeland system by delegating limited administrative power and opening up a new space for political expression. 
In the case of KwaZulu, grand apartheid saw the establishment of an executive, the KwaZulu Government, and a legislature, the Zululand Territorial Authority in 1970. In 1972 the KwaZulu Legislative Assembly (KLA) replaced the Territorial Authority. Both the executive and legislature were dominated by traditional leaders and both were led by the 'modernist' Mangosuthu Buthelezi, who out competed ‘monarchist' rivals aligned to the King Zwelithini (Forsyth 1989:50). Describing his job as one which 'makes one neither fish nor fowl'(APC PC1/5/1/10-76, 11 June 1970), Buthelezi was a conservative nationalist intent on 'using the system against itself' by advancing an anti-apartheid politics within the boundaries of government tolerance. In the event Buthelezi made little headway due to the intransigence of the apartheid state and the disinterest of his fellow homelands leaders (see Langner 1983:13-14). Consequently, he decided on another tack. Instead of just relying on his institutional status to advance his cause, he looked to mobilise popular support. Hence in 1975 Inkatha was launched.

Drawing its name from a proto-Zulu nationalist organisation of the 1920s (see Cope 1993), Inkatha was launched as a 'national cultural' movement open to Zulu people alone and endorsed by the KwaZulu Government. Even the name had specifically Zulu historical and political connotations ${ }^{\mathrm{i}}$. However, Inkatha was also a political project which was critical of apartheid during a highly repressive era when there was little by way of large-scale militant resistance politics inside South Africa. Thus Inkatha embraced the colours of the banned ANC, included many former ANC leaders and was formed with the support of key ANC leaders in prison and exile (Zulu 1994:per com). Importantly, Inkatha's ambiguous, hybrid identity was not simply the product of cautiously using the ethnic logic of apartheid as a Trojan horse for black liberation, but also because Inkatha wanted to incorporate the different constituencies of direct and indirect rule. Typically in KwaZulu- 
Natal's history, the urban intelligentsia and the working classes had been mobilised into quite different political projects from the traditional elite and peasantry (Marks 1986, Cope 1993).

These factors meant Inkatha embraced a ‘third-way’ politics between acquiescence in the apartheid status quo on the one hand and radical, mass resistance to apartheid on the other; a strategic orientation which manifested itself in a conservative-liberal ideology, symbolic as opposed to active resistance to apartheid and a hybrid identity politics. This basic pattern remained in place from 1975 until 1994 with one critical caveat: when Inkatha fared well it emphasised its national ambition, anti-apartheid politics and black credentials but when it fared poorly it defended its provincial orientation, its participation in KwaZulu and its Zulu credentials. Relatedly, when things went well Inkatha depicted the ANC as an ally and the apartheid government as the enemy, but when things went poorly, it portrayed the ANC as the greater threat. It is precisely the disjuncture between the remarkable continuity in its policies and the significant variance in its selfrepresentation which was Inkatha's defining feature. It is this dynamic which underwrote its ambiguous and instrumental relationship with Zuluness, whether it be nationalist discourse, traditional leaders or the Zulu King. Simply put, Inkatha's political elite did not want Zuluness, at least not on 'traditional' terms, but when things got tough they needed it.

From 1975 to 1979 Inkatha did well. Between 1976 and 1979 the movement grew from 30000 to 250000 (Mzala 1988:122) and a 1977 Freiburg survey found Buthelezi to be the most popular leader in Soweto, Durban and Pretoria. Similarly, a 1978 Bergstrassa Institute Study reported that Buthelezi led Mandela in popularity by $40 \%$ to $22 \%$. The latter poll found that $50 \%$ of Inkatha supporters also supported the ANC (Tessendorf \& Boult 1991:62). Importantly, rather than pursuing systematic organisation and mobilisation against apartheid, Inkatha's primary role seemed 
to be to legitimate Buthelezi as a leader worthy of national and international recognition and as the moderate intermediary between white and black. Buthelezi cultivated his 'representational' role adeptly, courting and being courted by a wide range of political groupings including Steve Biko’s South African Students Organisation (SASO), 'coloured' and white opposition parties, and even the State President John Vorster. Indeed in 1983 Buthelezi managed to bring together ‘moderate’ elites from Natal and KwaZulu in a mock constitution-making process called the Buthelezi Commission, a project which was followed a similar forum, the Indaba, in 1986. Concerned with finding a third way between apartheid and radical revolution, the Commission and Indaba were exercises in elite bargaining which, while provincial in practice, were intended as a model for a national constitutionmaking process.

Inkatha's growing confidence during the late 1970s was reflected also in its growing assertion of its black credentials and the evolution of its propaganda. In respect of the former, Buthelezi began to talk more and more about black liberation. Moreover, at the prompting of the ANC, Inkatha decided to open its membership to all black South Africans in 1979. In respect of its

propaganda, Buthelezi was increasingly articulating a discourse of black liberation harmonious with Zulu interests (Forsyth 1989:108, Temkin 1976). Indeed, by the early 1980s Inkatha's confidence had grown to the point where it was openly presenting itself as the rightful heir to the exiled ANC.

\subsection{Inkatha/ANC rivalry and 'hit and myth' politics, 1980 - 1989}

The 1980s witnessed a reversal of fortunes for Inkatha as previously cordial relations with the ANC evolved into a struggle for hegemony over black areas of KwaZulu-Natal. Out competed at the national level by ANC-aligned organisations like the United Democratic Front 
(UDF) and Congress of South African Trade Unions (COSATU), Inkatha looked to defend its provincial stronghold through violent confrontation (aided and abetted by the apartheid state) and a greater reliance on the KwaZulu homeland, the Zulu King, traditional leaders and a proto-Zulu nationalist discourse. It was this 'hit and myth' politics which evolved into the militant Zulu nationalism of the transition.

There are three reasons for the emergence of this violent struggle for territory. First was Inkatha's distance from the urban intelligentsia and working classes which drove the resistance politics of the 1980s. In 1975 Inkatha did enjoy some support from urban constituencies (Schahmann 1978:280, Sitas 1986:93-4) but soon lost this through its reliance on KwaZulu elites and institutions, the lack of a substantive anti-apartheid programme and its participation in apartheid's Black Local Authorities for the townships (Sutcliffe \& Wellings 1988). Second, by 1980 both the Inkatha and the ANC were markedly intolerant of alternative expressions of black resistance. Inkatha's intolerance was manifest both internally, in regular expulsions of burgeoning leadership and the lack of democratic culture, and externally in the party's defensiveness in the face of instances of militant resistance (Piper 2000:86). Similarly, during the 1970s the ANC was determined to established itself as the 'sole legitimate representative' of South Africa's oppressed (Lodge 1983:295), an attitude reflected in the UDF’s exclusion of any 'homeland’ party. Third, these rival leadership ambitions clashed at a meeting between Inkatha and the ANC in London in October 1979. Where Inkatha wanted recognition as an independent and 'vital force in the struggle' (Buthelezi 1992b:59-60), the ANC wanted Buthelezi to 'state his loyalty to the exiled leadership and allow the movement to operate in his homeland' (Davidson \& Strand 1993:52). Neither side conceded. The stage for the 1980 s was set. 
The politics of the 1980s was driven by an explosion of popular organisations and militant resistance politics in the urban areas of South Africa. Largely a response to the apartheid government's 'Total Strategy ${ }^{\text {ii }}$, more particularly its reforms in urban areas (Swilling \& Phillips 1989), the return of militant resistance politics took both Inkatha and the ANC by surprise. Beginning with the schools boycott of 1980, student protests were followed and surpassed by the growth of trade unions, civic organisations, the reawakening of Indian politics and the revival of congress culture associated with the ANC (Lodge \& Nasson 1991:35). By August 1993 this politics was given national expression in the United Democratic Front (UDF) which, at its peak, had 700 affiliates with two million members. The power of the UDF was demonstrated by the massive and militant revolts in the Vaal townships in 1984 and 1985 against the government's imposition of local government in the form of Black Local Authorities (Seekings 1991).

In KwaZulu-Natal it was only in 1985, after the assassination of UDF-aligned lawyer Victoria Mxenge, that township politics followed the Vaal example. However, unlike in the rest of South Africa, when traders and councillors became the targets of popular anger they were able to turn to Inkatha for support (Sitas 1986:105). Hence it was from this point that the IFP/ANC rivalry became a violent struggle for control over territory (Kentridge 1990). Notably, much of the violence centred around places not clearly demarcated as IFP or UDF, typically areas like squatter camps which fell between KwaZulu and established townships (Taylor \& Shaw 1997). Thus, the upshot of this violent contest was the sharpening of the pre-existing tendency towards a rural/urban pattern of political affiliation, with Inkatha's consolidating its hold over KwaZulu and surrounding rural areas and the UDF dominating most of the urban townships.

Inkatha's turn to 'hit and myth' politics was suggested as early as the student 
boycotts of 1980s. When Durban students ignored Buthelezi's order that they return to school, some were attacked by Inkatha supporters (Forsyth 1989:129). This incident is instructive in that, while both Inkatha and the UDF were equally dogmatic about their exclusive right to black representation, the available evidence from violence monitors, court cases, the TRC hearings and independent research suggests that Inkatha initiated more of the violent confrontation and certainly got the better of it (Aitchison 1993). What is indubitable is the fact that, despite initial denials to the contrary (Woods 1989, Buthelezi 1994), Inkatha was willing to take up arms against a rival but not against the state. Indeed, the evidence shows not only that the state aggravated this violent political rivalry, but almost invariably intervened on the side of Inkatha.

The 1980 student boycotts are also illustrative of Inkatha's turn to Zuluness. Buthelezi responded to the students disregard of his instructions by blaming 'non-Zulu agitators', 'Xhosa lawyers', 'foreign opportunists' and trade unions leaders for the boycotts, describing students as 'youth gone mad' (Mzala 1988:14, Naidoo 1991:153). It was also at this time that Buthelezi began asserting that Inkatha was the proper heir of the ANC, not the 'ANC mission-inexile' as he began to term it (Forsyth 1989:129). As the conflict with the UDF progressed, Inkatha's propaganda took on a more overtly Zulu nationalist flavour, ethnicising the Inkatha/UDF conflict as a Zulu/non-Zulu struggle. However, as Maré (1992:76) shows, the clearly political character of the conflict forced Inkatha to construct the 'enemy' as ethnic others plus Zulu 'traitors' by the late 1980s. It was this inconsistency that the ANC was to exploit later.

The turn to Zulu rhetoric was partnered by a greater reliance on traditional leaders, particularly as a result of violence in many rural areas adjacent to cities (Smith 1996:per com, see also Sitas 1990:258-9), but especially Buthelezi’s erstwhile enemy, King Zwelithini. From the mid- 
1980s Zwelithini invariably appeared at Buthelezi side echoing his speeches almost word for word (Forsyth 1989), effectively blurring ethnic and political boundaries. The following statement by Zwelithini is typical:

My people, when I say to you today that we cannot tolerate intimidations; when I command you to rout out those amongst you who undermine our national unity as a Zulu people; when I say to you enough is enough, we will not tolerate any further inroads into our dignity by the ANC in exile, by the UDF or by COSATU (in Davidson and Strand 1993:55).

If the violent competition for popular support prompted Inkatha to turn to Zuluness, it spurred its ANC-aligned rivals to denounce ethnicity and affirm a 'non-racial' nationalism. While the influence of the South African Communist Party on the ANC's 'non-racial' tradition and the radicalisation of the ANC in exile had already rendered ethnicity taboo (Bekker 1993), the conflict with Inkatha further delegitimised ethnic politics (Nzimande 1996). Instead, the UDF and COSATU embraced an anti-apartheid nationalism influenced by both socialism and African nationalism. This 'non-racial' nationalism recognised the existence of class and racial identities but held that these should not form the basis of social organisation (Taylor 1993). In sum then, on the eve of the negotiations period resistance politics in KwaZulu-Natal was violently polarised between the urban and rural. Urban areas were dominated by ANC-aligned organisations rooted in the intelligentsia and working classes. These organisations articulated a 'non-racial' nationalism that affirmed race and class identities over ethnic ones. Rural areas were controlled by Inkatha which relied heavily on the homeland classes, especially traditional leaders and invoked a Zulu ethnic discourse against supposedly 'ethnic' interlopers. 


\subsection{The rise of the politics of Zuluness, 1990 - 1994}

During the negotiations period from 1990 to 1994, Inkatha’s 'hit and myth’ strategy of confrontational tactics and Zulu rhetoric mutated into a more virulent form which climaxed in the militant Zulu nationalism of April 1994. Relaunched in 1990 as the Inkatha Freedom Party (IFP), Inkatha's turn to militant Zulu nationalism was driven by the same dynamic as the 1980s: political rivalry with the ANC. The difference in the 1990s was that the competition was no longer over the leadership of resistance politics, but rather over the process to, and content of, a post-apartheid state. As it found itself increasingly marginalised from negotiations, the IFP turned to confrontational tactics and Zulu rhetoric to raise the costs of its exclusion. Conversely, the negotiations period saw the ANC reverse its anti-ethnicity position of the 1980s embracing cultural difference as part of a multi-cultural 'rainbow' nationalism. As part of this, but primarily in reaction to the IFP's nationalism, the ANC in KwaZulu-Natal began affirming its Zulu character while rejecting Zulu nationalism. Thus the advent of negotiations marked the deepening and broadening of Inkatha's 'hit and myth’ politics of the 1980s into the 'politics of Zuluness' of the 1990s.

The rise of the politics of Zuluness between 1990 and 1994 can be periodised into three phases. The first phase stretches from the unbanning of the ANC on 2 February 1990 to the Conference for a Democratic South Africa (CODESA) I on 21 December 1991. It was marked by the evolution of an understanding between the elites of the ANC and NP over the process by which negotiations should proceed - specifically, that agreement between the two of them was both a necessary and sufficient basis for progress. For the IFP this was disastrous. From the outset it had wanted to be recognised as a necessary partner in negotiations (Felgate 1997:per com). Moreover,

the IFP had begun the negotiations period close to the NP until the 'Inkathagate' ${ }^{\text {iii }}$ scandal of July 
1991 prompted the NP to distance itself. The fundamental reason for the IFP's marginalisation however, was the perception by the ANC and NP that they held sufficient power, both popular and institutional, to make negotiations work. Consequently, the strategy of the IFP revolved around demonstrating that it enjoyed enough power to warrant full inclusion, and it looked to demonstrate this power through disrupting ANC/NP amity.

The second period, which ran from CODESA I through to the adoption of the interim constitution in late 1993, revolved around the ANC and NP defining the content of a post-apartheid state, while the IFP used confrontation and Zuluness to force its full inclusion. Although the IFP's problems with negotiations included the content of, as well as the process to, a post-apartheid state, these substantive issues took a back seat to procedural ones, not least as the ability to define the post-apartheid state was dependent on a process the IFP felt was appropriately inclusive. (Consistent with the Buthelezi Commission and the Indaba the IFP propagated a markedly federal vision of a future South Africa, not least as this would more likely preserve its power-base (Felgate 1997:per com)) The IFP's turn to confrontation took the form of brinkmanship in respect of the negotiations process and mobilisation in respect of mass politics. Brinkmanship involved protest and boycott of negotiations forums when the IFP's demands were not accommodated (see Tonkin 1996). These tactics were reinforced by popular mobilisation, for example marches bearing 'cultural weapons', and even violence. Thus, on 17 June 1992, at the same time as the ANC was trying to demonstrate its power through 'rolling mass action', Inkatha hostel dwellers attacked residents of the surrounding Boipatong township killing thirty-eight people. Indeed, the entire negotiations period was framed, almost to the week, by unprecedented political violence in the Reef townships, mainly between Inkatha hostel-dwellers and ANC township residents. 
The turn to confrontation went hand in glove with a turn to Zuluness. For example while the IFP attended CODESA I, Buthelezi boycotted in protest against the exclusion of the Zulu King and the KwaZulu government stating 'we seem to have latter-day imperialists who are denying the Zulu King and the Zulu Nation their birthright to participate in determining their future destiny’ (1992a). Another example was the IFP's defense of the Zulu right to carry 'cultural weapons', a claim it used to justify the bearing of crude weapons at its rallies. More generally the party began to wrap itself in the banner of Zulu nationalism, especially following the Record of Understanding of September $1992^{\text {iv }}$ which symbolised the ANC/NP commitment to successfully completing the negotiations process.

Interestingly it was during this time that the ANC in KwaZulu-Natal began to affirm Zuluness, if only rhetorically and through public display. At the 1992 May Day rally ANC leader Jeff Hadebe declared the importance of his Zuluness for his personal identity, provincial leaders began wearing traditional Zulu dress at public gatherings and hosted several alternative 'multicultural' Shaka Day rallies from 1992 to 1995. In part this was a reflection of the reversal of the ANC's anti-ethnicity position of the 1980s and the affirmation of a multi-cultural nationalism as summarised in its 'many cultures, one people’ slogan. More importantly, it was an attempt to contest the Zulu nationalism of the IFP (Nzimande 1996:per com). Essentially the message was that being Zulu did not mean being Zulu nationalist, and that the ANC was a home for Zulu people too.

The third phase of the politics of Zuluness saw the climax of the IFP's tendency towards militant Zulu nationalism in the first few months of 1994. As noted above, on the 17 January King Zwelithini told De Klerk that he ‘lay claim to the Zulu right of self-determination’ as 'the constitution under which some would wish to govern us is not predicated in our self- 
determination'. On the 14 January he made similar demands before a crowd of 100000 in Durban, and the IFP's mobilisation against the election swung into full gear. As Walter Felgate put it, 'the IFP wanted to show that there could not be an election in South Africa in which we did not participate'(1997:per com). It was in this fevered climate that the IFP and ANC finally squared off such that by late March mass action and violence has escalated to the extent that an ethnicallyjustified civil war loomed. The ANC matched the IFP's brinkmanship by pushing ahead with the election date of 27 April, leaving the IFP the choice of participating in the elections on compromised terms or boycotting and prosecuting a civil war. While the balance of power only made one option the logical one, the IFP's brinkmanship had gathered a momentum of its own which required some gentle diplomacy to break (Cassidy 1995:145-190).

\subsection{The decline of the politics of Zuluness, 1994 - 1999}

That the politics of Zuluness was driven by party interests was confirmed by its rapid decline from 1994 through 1999. Not only did invocations of Zuluness gradually retreat into the background of the KwaZulu-Natal ANC's discourse and public display, but militant Zulu nationalism was abandoned by the IFP in favour of more co-operative tactics and a multi-cultural rhetoric. There were three reasons for this. First, the issues which had divided the IFP from the ANC during the resistance and transition periods were decided. Second, the IFP was charmed and compelled to play by the rules of 'liberal-democratic' post-apartheid politics. Third, having learnt the costs of marginalising the IFP during the transition, the ANC discovered the benefits of including it in government, and ANC national leadership assiduously cultivated a closer relationship. Indeed, this was so successful that in 1997 rumours of merger abounded and after the national and 
provincial elections of 1999 the ANC and IFP voluntarily shared government at both national level and in KwaZulu-Natal.

However remarkable this rapprochement, it may well have taken place earlier had it not been for the IFP's last-gasp attempts to influence the national constitution late 1994 and early 1996 (Piper \& Hampton 1998). Embittered by the ANC's refusal to engage in international mediation and frustrated by the ANC's overwhelming majority (64.25\%) in the Constitutional Assembly, the IFP walked out. However, despite its boycott of the Constitutional Assembly, the IFP looked to challenge the remainder of the national constitution-making process through the drafting of a KwaZulu-Natal constitution. Moving from the premise that the national and provincial constitutions were of equal standing politically, if not legally (Smith 1996:per com), the IFP felt that if a strongly federal KwaZulu-Natal constitution was passed by the constitutional court before the national constitution, it would create a constitutional crisis and force 'further politics', perhaps even international mediation (Ambrosini 1995:per com). Further, as the majority party in KwaZulu-Natal the IFP believed it was well-placed to implement its version of the provincial constitution in the time required.

In the event the IFP failed. Not only did it not manage to secure the federal document it hoped for, but the constitutional court rejected it on the grounds that it was 'not consistent with the interim constitution and the constitutional principles' (Natal Witness 10/09/96). To this day, it has not been amended. The reason for the IFP's failure was quite simply that it did not understand the logic of liberal-democratic politics. In a situation where it needed two-thirds support of the KwaZulu-Natal legislature, the IFP held only forty-one of the eighty seats. The balance of the remaining seats was such that the IFP either had to bring on board the ANC or secure the support of 
every minority party other than the ANC. Not only did the IFP vacillate between these two options but the confrontational manner in which it tried to ram its constitutional vision through alienated all its potential allies, eventually forcing it into a series of compromises which rendered the final draft of the provincial constitution both less federal and less coherent (Piper \& Hampton 1998).

That the KwaZulu-Natal constitution-making process proved such a hard lesson in the logic of liberal-democratic politics is all the more remarkable given the IFP's move away from militant Zulu nationalism in other domains of politics after 1994. Thus, while there were moments when brinkmanship in negotiations was accompanied by mass confrontation and Zulu rhetoric, they remain isolated and infrequent. As IFP negotiator Mario Ambrosini put it, 'the struggle over the form of state has moved to the institutional domain' (1995:per com). Indeed, by the KwaZulu-Natal local government elections of June 1996 the IFP had been largely charmed and compelled into the new deal. It was charmed by its provincial victory and its participation in national government which gave it a stake in the institutions of democratic governance and prompted a turn to a more moderate politics. It was compelled by the public defection of the Zulu King ${ }^{\vee}$, sharing provincial government with a large and vigilant opposition, the surveillance of civil society and the slow return of law and order. These latter developments undermined its previous assets of Zulu nationalist rhetoric, monopoly of state institutions like KwaZulu and the freedom to organise violently. They also broke the IFP's exclusive hold over the old KwaZulu constituencies of the civil service, small business and traditional leaders. Indeed for the IFP the period after 1994 has been one of ambiguity, indecision and internal conflict as the strategies of the past have waned without being replaced by a coherent alternative.

These strategic shifts were reflected in the steady demise of the two defining features 
of the politics of Zuluness: violent confrontation and Zulu rhetoric. While the period following the 1994 election saw significant contests between the ANC and IFP, levels of violence declined steadily (HRC 1997), to the point that political violence has all but disappeared from KwaZulu-Natal today. Similarly Zuluness has waned from the rhetoric of both the IFP and the KwaZulu-Natal ANC. One only has to contrast the build-up to the 1994 national elections and 1996 local government elections in KwaZulu-Natal to appreciate this. Where in 1994 the IFP advocated a militant Zulu nationalism, in 1996 it made almost no reference to Zuluness, articulating a conservative-liberalism instead. This trend which has continued into the present. Correspondingly, whereas in 1994 the KwaZulu-Natal ANC was defending its Zulu credentials, in 1996 it was silent on the issue and has remained so ever since.

\section{Popular responses to the politics of Zuluness}

In explaining the invocations of Zuluness expressed during South Africa's transition as driven by party strategies this paper has offered an account of the instrumental embrace of ethnicity by political elites 'from above'. But what of the popular response to such invocations 'from below'? What did ordinary people, particularly Zulu people, feel about this politics? Were the IFP and ANC tapping into an already existing sense of Zulu ethnicity or even Zulu nationalism? Certainly the primordialist notions of Zuluness invoked by the IFP would presume that a popular nationalism existed. Further, the fact that the ANC in KwaZulu-Natal changed from denying the significance of Zuluness to affirming it implies that they thought it was a powerful discourse.

However, these views are too simplistic. The available evidence suggests that ordinary people were less affected by these nationalist discourses than is assumed. Simply put, I will 
argue that most Zulu people do see themselves as part of a Zulu people, an ethnic group, but they do not see themselves as part of a Zulu nation in the way the IFP put it, nor do they see themselves as part of a 'rainbow' nation in the way the KwaZulu-Natal ANC portrayed it. Rather, there exist a plurality of constructions of Zuluness, usually intertwined in complex ways with other identities like African, black and South African, which complicate the invocation of any one sense of nationhood. I will demonstrate my claims with reference to two sets of empirical evidence: (i) the voting behaviour of Zulu voters, and (ii) the self-understanding of Zulu people of their identity and voting behaviour.

The 1994 election, the 1996 local government elections, and the 1999 general elections have shed significant light on the distribution of party support in KwaZulu-Natal. While the violent and contested build-up to the 1994 election in KwaZulu-Natal cast a shadow over the accuracy of the results, they are arguably broadly indicative of the patterns of party support (see Piper \& Piper 1995). On the provincial ballot the IFP won 50.3\% with the ANC in second place with 32.2\%. More importantly, the distribution of support for the IFP and ANC was not even across the province but followed racial and rural/urban divides. In brief, almost all black voters supported either the IFP or the ANC, and the IFP and ANC's votes were overwhelmingly from black, rather than white, indian or coloured, voters. Moreover, the dividing line between IFP and ANC voters was not ethnic but rural/urban such that rural black voters endorsed the IFP and urban black voters the ANC. Lastly, within rural areas there was a suggestion that black people who did not speak Zulu voted for the ANC rather than the IFP (Ibid). If this was the case (and the evidence is insufficient to safely make the claim) it is consistent with the national trend. In effect then, the IFP and ANC split the provincial Zulu vote 60:40 respectively. This finding is consistent with my account of the history 
of IFP/ANC competition for territory during the 1980s. Moreover, given that roughly two-thirds of Zulu South Africans are located in KwaZulu-Natal and that only 10\% of the IFP's support came from outside the province, it suggests that less than 50\% of Zulu people supported the IFP in 1994.

These patterns were unequivocally confirmed by the 1996 local government elections and the 1999 election results. The 1996 results were important both because the integrity of the election process was maintained to a much greater extent than in 1994 and because the local government electoral system meant that party support could be traced down to local areas. Constructing a makeshift comparison with 1994, the IFP won 44.5\% of the vote and the ANC 33.2\% (see Piper 2000:176). Further, both the isomorphism between the IFP/ANC and black KwaZuluNatalians and the urban/rural divide were demonstrated in detail (Ibid:175-182). Thus, once again, it was the case that rural Zulu people supported the IFP and urban black people the ANC. Lastly, this pattern was repeated in the 1999 election of 2 June, with one important caveat, the ANC began to make inroads into the IFP's rural support-base, mainly in the south of the province (Piper 1999). This shift also explains the closeness of the race in the province with the IFP securing $40.45 \%$ of the vote and the ANC 39.78\%.

These trends are important because they reveal the inaccuracy of the nationalist discourses of both the IFP and ANC during the era of the politics of Zuluness. First, the IFP's claims to represent the Zulu nation are evidently false. Today, and in 1994, the IFP can claim the support of most Zulu people in the province of KwaZulu-Natal but it cannot claim the support of most Zulu South Africans. Indeed, this honour goes to the ANC. Patently then, the IFP is not the party of the Zulu nation. Second, the racial nature of party support suggests that the ANC's multi-cultural nationalist alternative is probably little more than wishful thinking. Support for his hypothesis is 
offered by Mathieson and Attwell's (1995) account of the ANC's attempts at 'multi-cultural' Shaka Day in 1995. Hosted in the ANC-supporting rural area of KwaXimba, the community chose to affirm local history, traditions and identity over the multi-cultural nationalist content advocated by the ANC. Third, the importance of the history of party agency in influencing the popular vote is revealed by the high correspondence between the urban/rural distribution of popular support and the urban/rural distribution of party hegemony. The importance of party agency was confirmed by the ANC's gains in rural areas where it campaigned the hardest in the 1999 election. These voting patterns suggest that the nationalist discourses of the transition were probably less important in securing popular support than (often violent) party agency.

Given the intense nature of the politics of Zuluness during the transition it seems safe to infer that had most Zulu people endorsed some form of Zulu nationalism they would have been moved to support the IFP, or at least not endorse its overt rival, the ANC. Consequently the pattern of party support outlined above calls into question whether most Zulu people see politics in ethnic nationalist terms. This hypothesis is confirmed by existing research into the self-understanding of Zulu South Africans which reveals that although most identify themselves as members of the Zulu people on various grounds (language, place, descent, customs), the constructions of this vary widely. Most seem to intertwine their Zuluness with being black or African, or even subsume it to the latter (Sitas 1990, Campbell et al 1995), confounding the basis for a simple Zulu nationalism. Furthermore, research into the reasons given by voters for their choice of party has found that racial or ethnic identities were almost never cited. The only significant exception here is for IFP voters in the 1994 election, where 44\% said they supported the IFP because they were Zulu (Mattes 1995:856). Thus, according to Mattes research, only 26\% of Zulu voters in 1994 can be said to be ethnic 
voters, a statistic made all the more remarkable given that this was when militant Zulu nationalism was at its zenith.

While far from complete, the existing empirical evidence supports the view that IFP and ANC nationalist discourses enjoyed limited popular resonance. Perhaps this is because there is not a widely-held and common national consciousness amongst Zulus/blacks/Africans/South Africans. Certainly many social histories of KwaZulu-Natal have pointed to the hybrid and intertwined ways in which supposedly rival national identities of 'Zulu' and 'black' have been intertwined (Sundkler 1961,Vilakazi et al 1986, la Hausse 1992), making political mobilisation around a particular identity like 'Zuluness’ all that more difficult. Example after example of ethnic and nationalist conflict has demonstrated how difficult it is to contain and reverse such conflict once it has begun. Fortunately in the peculiar case of the politics of Zuluness, the ethnic genie was not let out the political bottle. The reason for this was not simply the fact that the IFP was using Zulu nationalism for party political ends, nor simply that the conflict was political rather than ethnic, but also because most Zulus do not embrace a Zulu nationalist consciousness. Without this shared political belief, the Zulu nation does not exist, even while the Zulu ethnic group does.

\section{Conclusion}

The rise and fall of Zulu nationalism during South Africa's transition from apartheid to democracy was primarily about the manipulation of an identity to serve party ends. This argument echoes a longstanding leftist critique of the strategic embrace of Zuluness by Inkatha, but eschews the tendency to see Inkatha simply as an apartheid satrap. What is new is not the point that the IFP advanced a more conservative flavour of resistance politics, nor that it did so on the back of rural 
constituencies often marginalised from popular mobilisation, but rather that Inkatha initially embraced a 'third way' politics between the ‘unacceptability' of acquiescence in apartheid and the 'impossibility’ of mass, militant resistance. It was only when out competed by ANC aligned rivals in urban areas and at national level that Inkatha turned to Zuluness, defended its participation in apartheid structures and looked to consolidate provincial power. Thus Zulu politics was a second choice strategy driven by competition with the ANC and its allies.

Moreover, this analysis of Inkatha's original strategy as one of'third-way politics' reveals an originality and boldness typically overlooked. It was a politics that eschewed the binary oppositions in which both the apartheid state and the ANC saw South African politics, and it was a politics that looked to link both urban and rural, racial and ethnic, and national and provincial constituencies. Thus despite being presented as pragmatic, Inkatha's politics were hugely ambitious, a feature which bears the mark of its creator and driving force, Mangosuthu Buthelezi. Thus, while Inkatha began as the project of the conservative black middle classes (see Langner 1983:17-18, Maré \& Hamilton 1987:61; Tessendorf \& Boult 1991:13) there is no doubt that it became and remains the fiefdom of the chief. With his national leadership ambitions now sated, his party is withering on the vine. Thus the evolution of Inkatha politics from a bold and original resistance strategy to a second-choice defensive Zuluness parallels the evolution of it as a movement representing the concerns of the black middle classes to one representing the will of a patriarch.

If the evolution of Inkatha's politics and organisational character was the result of contingent factors, it is nevertheless a history set against the backdrop of state formation and reformation in South Africa. Without understanding the bifurcation of the state into rural and urban with their divergent rules, legitimating discourses, elites and constituencies one cannot understand 
Inkatha, KwaZulu-Natal or South Africa's transition politics adequately. Consequently, my argument affirms the recent trend towards taking the state more seriously in South African studies (Posel 1991, Mamdani 1996, Marx 1998). Moreover, the instrumental characters of Inkatha's relationship with Zuluness suggests an instrumental relationship with the rural constituencies it claims to represent. Indeed, it is hard to find instances where Inkatha has advanced the interests of rural people outside of protecting the patriarchal power-relations the party relies on for popular support. Now that the party is snugly ensconced with the urban-orientated ANC, the interests of rural constituencies are even less likely to be advanced.

The cohabitation in government of the IFP and ANC also poses a problem for rightist readings of Inkatha as a Zulu nationalist project. While certain conservatives might point to a basis for this in a shared conservative African nationalism, the relational nature of Inkatha's turn to Zuluness explodes the authenticity of Inkatha's Zulu nationalism. As a second choice, defensively embraced and easily jettisoned, Zulu nationalism cannot be the fundamental passion stirring in Inkatha's breast. Moreover, through association with Inkatha, Zulu nationalism has a petulant and traditional flavour unpalatable to the intelligentsia who usually drive cultural nationalism. Inkatha has discredited Zulu nationalism in the eyes of those seeking an authentic political expression of 'black culture’.

Lastly, while the instrumental invocation of Zuluness by both Inkatha and the ANC during the transition suggest its popular resonance, so diverse are the popular interpretations of what it is to be Zulu and how that relates to being African or black, that neither the Zulu nor 'rainbow' nations can be said to exist. As demonstrated by recent work in social history, 'Zuluness' and 'Africanness' are often intertwined in hybrid ways, so blurring the grounds of an exclusive 
nationalism This point rebuffs primordialist assumptions of many, especially western, observers who elide Zuluness and Zulu nationalism in same way Verwoerd slouched from 'whiteness' to apartheid. In concert with an essentialised reading of race, this mind set has informed a conservative pluralist tradition in South African studies which sees politics as about relations between mutuallyantagonistic groups (Horowitz 1991, Lijphardt 1993, Johnson \& Schlemmer 1996). The political indeterminacy of Zuluness undermines the ontological basis of this tradition. For the foreseeable future then, both Zulu nationalism and the Zulu nation are dead.

i. In the Zulu kingdom the Inkatha was the symbol of Zulu unity and nationhood. It consisted of a grass coil, the circular form of which was believed to have the power of joining together a dispersed people in affiliation to the King. Roughly a metre in diameter, the Inkatha contained sacred ingredients including the insula (body dirt) of the King and his predecessors, which were added to over the years, all of which was wrapped in python skins and bound with grass rope. Handed down from generation to generation, the Inkatha used by Shaka was kept until Cetshwayo’s royal kraal was burnt by the British in 1879 (Dlamini 1986:29).

ii. Designed to secure the long-term survival of capitalism against the supposed communist 'Total Onslaught', Total Strategy represented the ascendancy of ‘securocrats' associated with the new Prime Minister, P.W. Botha. Ideologically in tandem with the verligte or enlightened wing of the NP, the securocrats were mostly military men who dominated 
strategic thinking in the Botha years (O’Meara 1983:252). Drawing on Cold War counter-insurgency theory Total Strategy looked to modify access to official institutions so as to open divides in the African population. It further looked to address material grievances at local level, while eliminating the 'radicals' who mobilised around such grievances. Despite its strategic sophistication however, Total Strategy had little by way of an ideological vision which could compete with its liberal and liberatory rivals (Swilling \& Phillips 1989). In short, it was an unconvincing combination of reform and repression.

iii. In July 1991 the Weekly Mail newspaper exposed clandestine government funding of Inkatha 'anti-sanctions' rallies during the 1980s, undermining Inkatha’s claims to independence from the apartheid government.

iv. While fundamentally a set of government concessions to facilitate the resumption of negotiations after a period of mass action and violence (Atkinson 1994:14), the Record of Understanding included a government commitments to fencing and patrolling IFP dominated hostels on the Rand and the prohibition of the carrying of 'cultural weapons'. Although largely symbolic, these commitments confirmed for the IFP its marginalisation from the negotiations process.

v. In September 1994 Zwelithini publicly repudiated Buthelezi's claims to be 'traditional Prime Minister' of the Zulu nation, reportedly saying to Mandela, 'You were a prisoner for 27 years. I was a prisoner under Buthelezi for 24' (Weekly Mail \& Guardian 
23/09/94). Zwelithini's move threatened to puncture a hole in the IFP's ideological balloon and undermine Buthelezi's standing and so a fierce battle ensued for the loyalty of the traditional elite. After a series of rival gatherings, boycotts of each others events, appeals to national and provincial governments, and the like, a stalemate was reached: Buthelezi had begrudgingly accepted the reality of Zwelithini’s independence and Zwelithini was well aware of Buthelezi’s greater support amongst the traditional elite. 